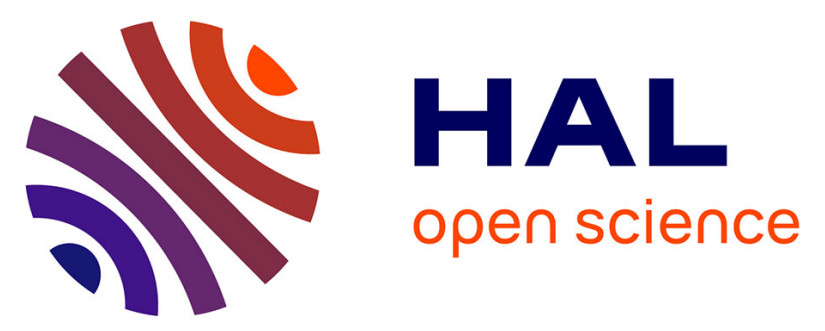

\title{
Is the apocrine milk secretion process observed in the goat species rooted in the perturbation of the intracellular transport mechanism induced by defective alleles at the $\alpha \_$s1-Cn locus?
}

Carole Neveu, Alain Riaublanc, Guy Miranda, Jean-François Chich, Patrice Martin

\section{To cite this version:}

Carole Neveu, Alain Riaublanc, Guy Miranda, Jean-François Chich, Patrice Martin. Is the apocrine milk secretion process observed in the goat species rooted in the perturbation of the intracellular transport mechanism induced by defective alleles at the $\alpha$ s1-Cn locus?. Reproduction Nutrition Development, 2002, 42 (2), pp.163-172. 10.1051/rnd:2002015 . hal-00900373

\section{HAL Id: hal-00900373 https://hal.science/hal-00900373}

Submitted on 1 Jan 2002

HAL is a multi-disciplinary open access archive for the deposit and dissemination of scientific research documents, whether they are published or not. The documents may come from teaching and research institutions in France or abroad, or from public or private research centers.
L'archive ouverte pluridisciplinaire HAL, est destinée au dépôt et à la diffusion de documents scientifiques de niveau recherche, publiés ou non, émanant des établissements d'enseignement et de recherche français ou étrangers, des laboratoires publics ou privés. 


\title{
Is the apocrine milk secretion process observed in the goat species rooted in the perturbation of the intracellular transport mechanism induced by defective alleles at the $\alpha_{s I}-\mathrm{Cn}$ locus?
}

\author{
Carole Neved ${ }^{\mathrm{a}, \mathrm{b}}$, Alain Riaublanc ${ }^{\mathrm{c}}$, Guy MiRANDA ${ }^{\mathrm{d}}$, \\ Jean-François $\mathrm{CHICH}^{\mathrm{e}}$, Patrice MARTIN ${ }^{\mathrm{b} *}$
}

\author{
${ }^{a}$ Laboratoire de Recherches de Technologie Laitière, Institut National de la Recherche \\ Agronomique, 65 rue de Saint Brieuc, 35042 Rennes Cedex, France \\ b Laboratoire de Génétique Biochimique et de Cytogénétique, Institut National de la Recherche \\ Agronomique, Domaine de Vilvert, 78352 Jouy-en-Josas Cedex, France \\ ${ }^{\mathrm{c}}$ Laboratoire d'Étude des Interactions des Molécules Alimentaires, Institut National de la \\ Recherche Agronomique, La Géraudière BP 71627, 44316 Nantes Cedex 3, France \\ ${ }^{d}$ Unité de Biochimie et de Structure des Protéines, Institut National de la Recherche \\ Agronomique, Domaine de Vilvert, 78352 Jouy-en-Josas Cedex, France \\ e Unité de Virologie et Immunologie Moléculaires, Institut National de la Recherche \\ Agronomique, Domaine de Vilvert, 78352 Jouy-en-Josas Cedex, France
}

\begin{abstract}
The structural and quantitative variability of caprine $\alpha_{\mathrm{s} 1}$-casein induced by the extensive polymorphism recorded at the corresponding locus strongly influences the composition (proteins as well as lipids) and the technological behaviour of milk. Immuno-histo-chemistry studies coupled with electron microscopy analysis have shown that a dysfunction exists in the intracellular transport of caseins when $\alpha_{\mathrm{s1}}$-casein is lacking. Casein accumulation in the endoplasmic reticulum leads to a dilation of the cisternae that could disturb the whole secretion process (including lipids). Despite a long controversy, goat milk secretion is still considered to occur through an apocrine process contrary to the merocrine process described for cow's milk. We suggest that the apocrine pathway of secretion described in the goat could be the consequence of the dysfunction observed in the intracellular transport of caseins when $\alpha_{s 1}$-casein is lacking. To obtain further clues in the favour of such a hypothesis, we compared the protein and lipid fractions of milks from goats homozygous for different $\alpha_{\text {s1 }}$-casein alleles.
\end{abstract}

genetic polymorphism / $\alpha_{\mathrm{s} 1}$-casein / secretion / apocrine / goat milk

\footnotetext{
* Correspondence and reprints

E-mail: martin@diamant.jouy.inra.fr
} 
Résumé - Le processus de sécrétion apocrine du lait décrit chez la chèvre ne trouverait-il pas son origine dans la perturbation du transport intracellulaire induit par les allèles défectifs détectés au locus $\alpha_{s 1}-\boldsymbol{C n}$ ? La variabilité structurale et quantitative de la caséine $\alpha_{\mathrm{s} 1}$ caprine consécutive au fort polymorphisme décrit au locus correspondant exerce une forte influence sur la composition (protéique mais aussi lipidique) et le comportement technologique du lait. Des études d'immuno-histo-chimie couplée à la microscopie électronique ont révélé l'existence d'un dysfonctionnement du transport intracellulaire des caséines en cas de déficience en caséine $\alpha_{\mathrm{s} 1}$. L'accumulation de caséines dans le réticulum endoplasmique entraîne une dilatation des citernes qui pourrait perturber l'ensemble des mécanismes sécrétoires (lipides notamment). Malgré une longue controverse, on attribue aujourd'hui encore à la chèvre un processus de sécrétion du lait de type apocrine contrairement à la sécrétion de type mérocrine décrite chez la vache. Nous suggérons que la sécrétion apocrine décrite chez la chèvre pourrait découler du dysfonctionnement des mécanismes de transport intracellulaire des caséines observé en cas de déficience en caséine $\alpha_{\mathrm{s} 1}$. Afin d'obtenir des indices supplémentaires en faveur d'une telle hypothèse les fractions protéiques et lipidiques de laits d'individus homozygotes pour différents allèles de caséine $\alpha_{\mathrm{s} 1}$ ont été comparées.

polymorphisme génétique / caséine $\alpha_{\mathrm{s} 1}$ / sécrétion / apocrine / lait de chèvre

\section{MOLECULAR BASIS OF $\alpha_{S 1}$-CASEIN POLYMORPHISM}

To date, at least 18 alleles have been described (Fig. 1) and shown to be associated with 4 different levels of $\alpha_{\mathrm{s} 1}$-casein $\left(\alpha_{\mathrm{s} 1}-\mathrm{Cn}\right)$ in milk designated as "strong", "medium", "low" and "null" [5, 10]. Thus, a strong level is observed for alleles As*, $\mathrm{B}_{1-4}, \mathrm{C}$ and $\mathrm{L}$ with an estimated $7.2 \mathrm{~g}$ of $\alpha_{\mathrm{s} 1}-\mathrm{Cn}$ per litre of milk and allele $\mathrm{H}$ with $8.4 \mathrm{~g} \cdot \mathrm{L}^{-1}$. These strong alleles only differ in amino acid, with $B_{1}$ the variant exhibiting the closest homology with its bovine and ovine counterparts and being thus considered as the original one in the goat species. Assuming so, the "normal" level in the species would be the high one and medium, low and null alleles thus constitute defective mutants.

Medium alleles E and I approximately contribute only $1.6 \mathrm{~g}$ of $\alpha_{\mathrm{s} 1}$-Cn per litre of milk but share primary protein structure with the strong $\mathrm{B}_{4}$ and $\mathrm{A}$ variants, respectively. The $\mathrm{E}$ allele is characterised by the insertion of a LINE sequence of 458 nucleotides in the 3' UTR of the 19th and last exon of the gene that could be involved in the reduction of the $\alpha_{\mathrm{s} 1}-\mathrm{Cn}$ synthesis rate by exercising a negative effect upon the translation and/or the stability of the relevant messenger [13]. At the moment, no information is available on the factor(s) responsible for the medium content of $\alpha_{s 1}-\mathrm{Cn}$ associated with allele I.

Low alleles $\mathrm{F}$ and $\mathrm{G}$ contribute $0.6 \mathrm{~g}$ of $\alpha_{s 1}$-Cn per litre of milk and both present an internal deletion of 37 and 13 amino acid residues, respectively. The 37 residue deletion observed in variant $F$ arises from an outsplicing of exons 9,10 and 11 probably due to a single base deletion occurring in the first unspliced exon (exon 9) [15]. A minimum set of 9 different transcripts, differing in their splicing patterns, has been characterised so far. Four of them lack exons 9, 10 and 11 (short forms), whereas the others, belonging to the "long form" class, are more or less properly spliced transcripts with three of which showing a frame shift leading to the occurrence of a prematured stop codon. The deletion occurring in variant $\mathrm{G}$

\footnotetext{
* Studies on the polymorphism at the DNA level have revealed that the A allele can be divided into four subtypes, on the basis of intronic mutations (Leroux et al., manuscript in preparation).
} 


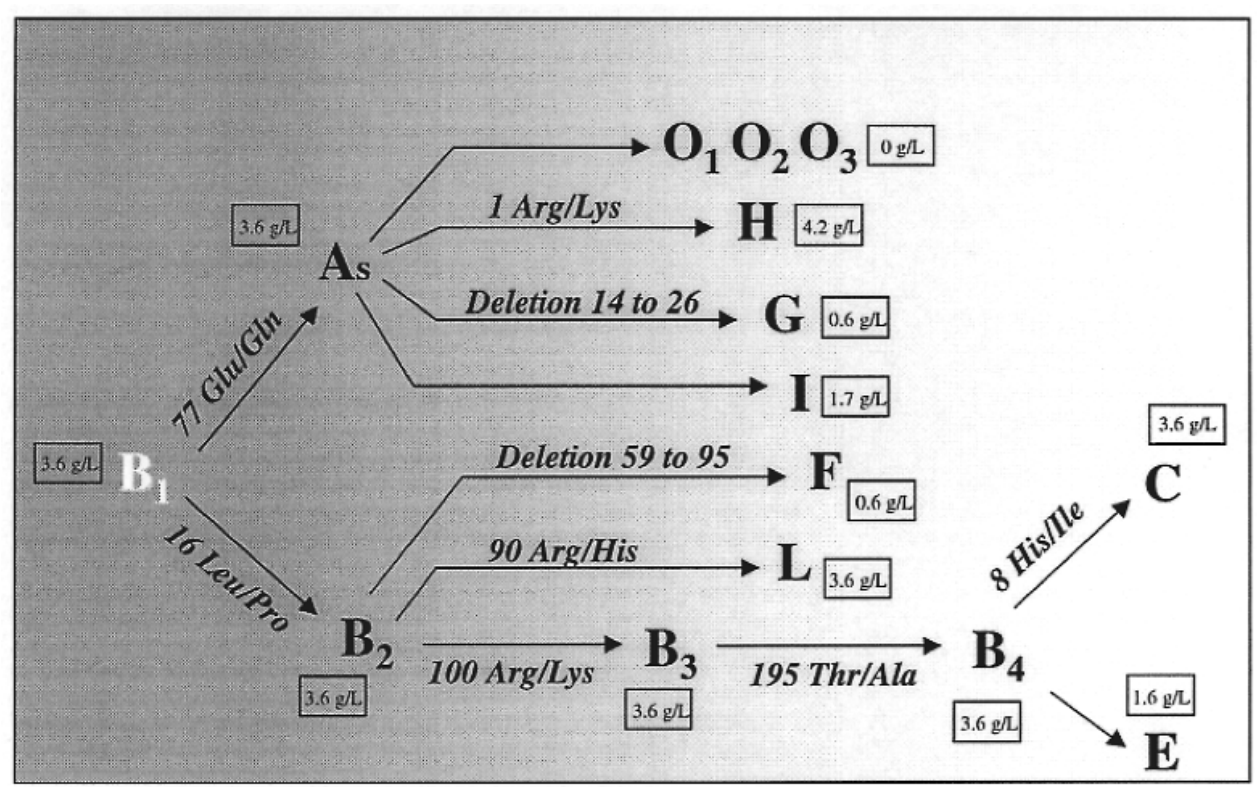

Figure 1. Phylogeny of goat $\alpha_{s 1}$-Cn alleles: molecular differences between corresponding variants and $\alpha_{s 1}-\mathrm{Cn}$ content in milk, per allele $[5,10]$.

is also generated by an exon-skipping event (exon 4) triggered by the $\mathrm{G} \rightarrow \mathrm{A}$ transition at the first position in the intron 4 donor splice site [18]. Whereas the 37 residue deletion leads to the loss of a hydrophilic cluster of five contiguous phosphoseryl residues: 64SerP-SerP-SerP-SerP-SerP-Glu-Glu70 in the $\mathrm{F}$ protein, the 13 residue deletion conversely affects a rather hydrophobic sequence which is removed in the very $\mathrm{N}$-terminal part of the $\mathrm{G}$ variant.

As far as null alleles are concerned, three different mutations have been identified. $\mathrm{O} 1$ is characterised by a large deletion and $\mathrm{O} 2$ by a large insertion (Leroux and Martin, manuscript in preparation). The third null allele is currently under investigation.

Strong alleles are considered to be the original genotype in the goat species but defective alleles can be (or have been) predominant in several populations including the widespread cosmopolitan Alpine and Saanen breeds [10].

\section{EFFECTS OF THE $\alpha_{s 1}$-CASEIN POLYMORPHISM ON MILK PROPERTIES}

For obvious economical reasons and with the aim of improving the efficiency of breeding selection programs, the effects of such a complex polymorphism on milk properties and technological abilities have been studied (Tab. I).

High levels of $\alpha_{\mathrm{s} 1}$-Cn have been found to be associated with higher total protein and casein contents, smaller casein micelles containing less calcium, better cheese-making potential with higher yields and firmer curds $[6,11,21]$ but poorer organoleptic character with a less pronounced goat flavour. It was subsequently shown that flavour development is partly linked to lipolysis which appears to be lower in milks with high protein content [7, 14, 24]. Such an impact of the $\alpha_{\mathrm{s} 1}$-Cn polymorphism on the lipid fraction of milk was rather unexpected. It is noteworthy that there is not only a quantitative effect 
Table I. Physico-chemical and technological characteristics of AA, EE and FF milks: means and statistical comparison (adapted from [21]). Values followed by a different letter on the same line are significantly different $(P=0.05)$.

\begin{tabular}{lccc}
\hline & \multicolumn{3}{c}{ Genotype } \\
\cline { 2 - 4 } & $\begin{array}{c}\text { AA } \\
(n=51)\end{array}$ & $\begin{array}{c}\mathrm{EE} \\
(n=51)\end{array}$ & $\begin{array}{c}\mathrm{FF} \\
(n=51)\end{array}$ \\
\hline Total proteins $\left(\mathrm{g} \cdot \mathrm{L}^{-1}\right)$ & $31.8^{\mathrm{a}}$ & $27.6^{\mathrm{b}}$ & $25.5^{\mathrm{c}}$ \\
Casein $\left(\mathrm{g} \cdot \mathrm{L}^{-1}\right)$ & $26.7^{\mathrm{a}}$ & $22.8^{\mathrm{b}}$ & $20.7^{\mathrm{c}}$ \\
Fat $\left(\mathrm{g} \cdot \mathrm{L}^{-1}\right)$ & $33.5^{\mathrm{a}}$ & $31.8^{\mathrm{a}, \mathrm{b}}$ & $29.2^{\mathrm{b}}$ \\
Total calcium $\left(\mathrm{mg} \cdot \mathrm{L}^{-1}\right)$ & $1200^{\mathrm{a}}$ & $1090^{\mathrm{b}}$ & $1050^{\mathrm{b}}$ \\
& & & \\
Micelle characteristics & & & \\
$\quad$ Average diameter (nm) & $221^{\mathrm{a}}$ & $264^{\mathrm{b}}$ & $268^{\mathrm{b}}$ \\
$\quad$ Mineralisation (mg Ca.g & $31.6^{\mathrm{a}}$ & $33.4^{\mathrm{b}}$ & $34.3^{\mathrm{b}}$ \\
Renneting behavein) & & & \\
$\quad$ Rennet clotting time (min) & $15.1^{\mathrm{a}, \mathrm{b}}$ & $16.6^{\mathrm{a}}$ & $13.7^{\mathrm{b}}$ \\
$\quad$ Gel firming rate $\left(\mathrm{mm} \cdot \mathrm{min}^{-1}\right)$ & $3.56^{\mathrm{a}}$ & $2.68^{\mathrm{b}}$ & $2.85^{\mathrm{b}}$ \\
$\quad$ Maximum gel firmness (mm) & $50.4^{\mathrm{a}}$ & $40.5^{\mathrm{b}}$ & $37.3^{\mathrm{c}}$ \\
\hline
\end{tabular}

but also a qualitative effect of $\alpha_{\mathrm{s} 1}$-Cn deficiency, low levels of the protein being associated with lower fat contents [1], with creaming and skimming difficulties (unpublished results) and with a more intense lipolysis giving rise to a stronger goat flavour [7, 14, 24].

Altogether, these observations led to the hypothesis that a global effect acts on the cellular mechanisms involved in the secretion of milk components.

\section{EFFECTS OF THE $\alpha_{s 1}$-CASEIN POLYMORPHISM ON THE INTRACELLULAR TRANSPORT OF MILK PROTEINS AND MILK SECRETION}

Comparative electron microscopic studies of lactating goat mammary epithelial cells (MEC) suggest that a dysfunction exists in the secretory mechanisms in animals homozygous for defective alleles $(\mathrm{O}, \mathrm{F}$ or $\mathrm{G}$ and to a lesser extent, E). Intracellular transport of newly synthesised caseins is strongly slowed down leading to the accumulation of immature forms in the cisternae of the rough endoplasmic reticulum (ER) which take on a dramatically dilated shape [4] (Fig. 2). It is noteworthy that there is an inverse correlation between the accumulation of caseins in the ER and the level of $\alpha_{\mathrm{s} 1}-\mathrm{Cn}$ in this compartment. Nevertheless, the rate at which $\alpha_{\mathrm{s} 1}-\mathrm{Cn}$ is transported out of the ER seems to remain constant. Interestingly, MEC in which the $\beta$-Cn gene is not expressed do not show accumulation of immature caseins in the ER. It is noteworthy that in both cases (lack of $\beta$ - or $\alpha_{\mathrm{s} 1}-\mathrm{Cn}$ ), casein micelles are still observed in the secretory vesicles suggesting that $\beta$ - or $\alpha_{\mathrm{s} 1}$-Cn are not absolutely necessary for the formation of micelles. One can therefore expect that micellar structural organisation does not follow a unique and strictly defined pattern. Taken together, these observations suggest that $\alpha_{\mathrm{s} 1}-\mathrm{Cn}$ is required for the optimal transport of all the other caseins with which it would interact in an heterooligomeric complex, promoting their transport to the Golgi apparatus. In addition, 

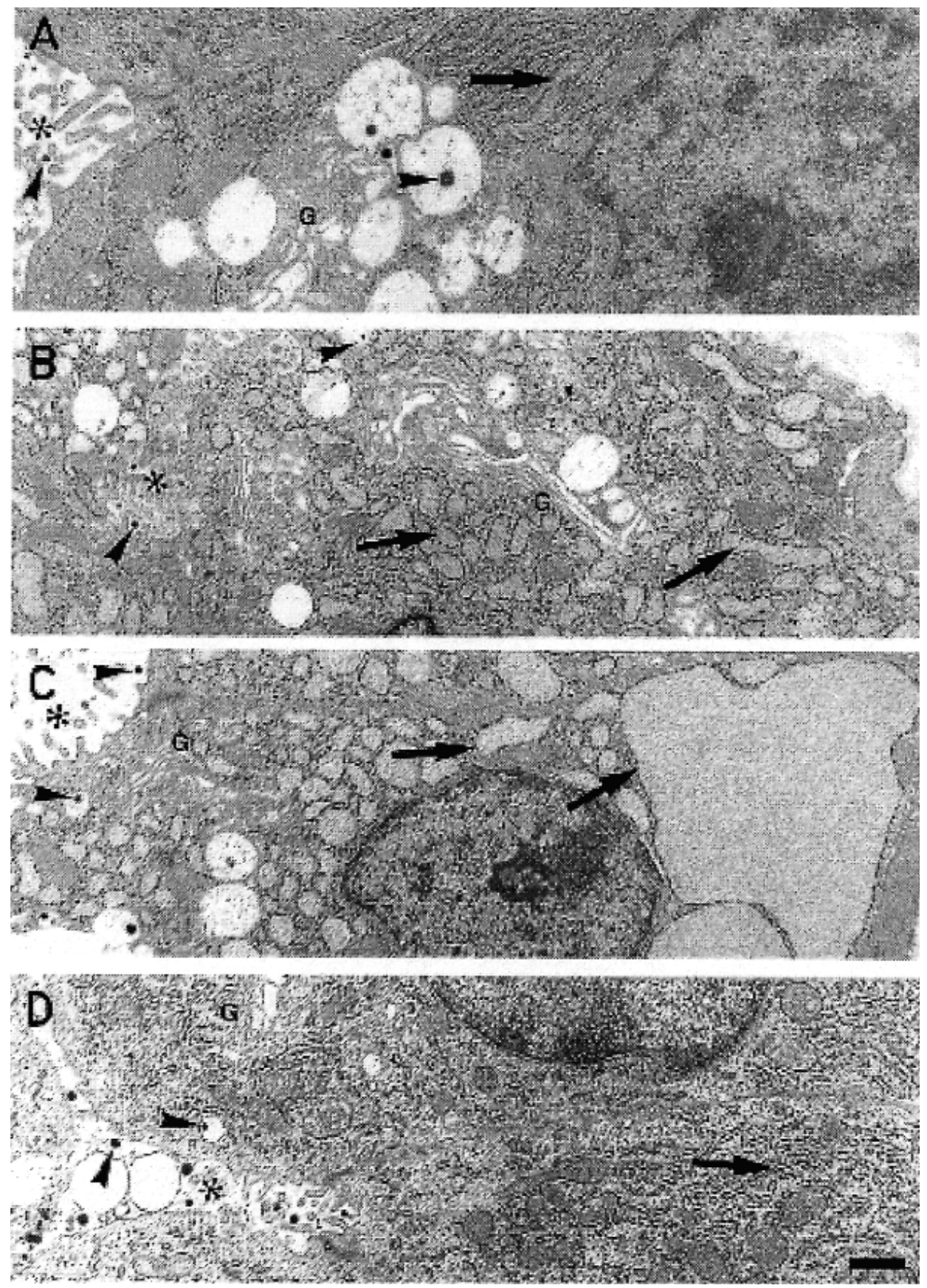

Figure 2. Morphology of MEC from lactating goats homozygous for distinct $\alpha_{s}-C n\left(\mathrm{~A}=\alpha_{\mathrm{s} 1} \mathrm{~A}\right.$, $\left.\mathrm{B}=\alpha_{\mathrm{s} 1} \mathrm{E}, \mathrm{C}=\alpha_{\mathrm{s} 1} \mathrm{O}\right)$ or $\beta$-Cn alleles $(\mathrm{D}=\beta \mathrm{O})$. Note the remarkable enlargement of the RER cisternae (arrows) of MEC from $\alpha_{s l}-\mathrm{CnO} / O$ goats (C) and to a lesser extent from $\alpha_{s 1}-\mathrm{CnE} / \mathrm{E}$ goats (B). Arrow heads $=$ Cn micelles; asterisk $=$ lumen; $\mathrm{G}=$ Golgi. Bar $=1 \mu \mathrm{m}[4]$. 
$\alpha_{\mathrm{s}}$-Cn has been shown to possess some chaperone-like properties and to solubilise hydrophobically aggregated proteins [3].

\section{CELLULAR MECHANISMS FOR MILK SYNTHESIS AND SECRETION}

A merocrine process, consisting in the passage of milk components through the apical cell membrane to the alveolar lumen without loss of the cytoplasm, is the generally admitted view of milk secretion (Fig. 3). In fact, four secretory processes are known to co-exist in the MEC of lactating mammary glands [22]: a poorly understood transmembrane secretion of some ions and water at the apical or basolateral membrane of the cell, transcytosis of intact interstitial molecules such as immunoglobulins, hormones or albumin, exocytosis of virtually all the aqueous phase components and a particular lipid synthesis and secretion. A fifth pathway, the paracellular pathway, allows the direct transfer of molecules as large as immunoglobulins between the milk and the interstitial space but it is only open during pregnancy, mammary gland involution or in the presence of mastitis [22]. Quantitatively speaking, exocytosis and lipid secretion appear to be the most important secretory processes.

The exocytosis pathway is rather well known. Proteins newly synthesised on ribosomes enter the rough ER where their signal peptide is cleaved and the protein molecules are folded. Vesicles then transfer them to the Golgi stacks where they are further processed (phosphorylation, glycosylation, etc.) and packed into secretory vesicles. Many other molecules accumulate in the Golgi vesicles such as lactose which draws water inside, citrate, calcium, phosphate, etc. The Golgi apparatus is also the scene of casein micelle formation. Immature forms of casein molecules interact and condense in the cisGolgi; phosphorylation, glycosylation and calcium arrival lead to the maturation of casein micelles into spherical particles sufficiently dense to be easily observed in the secretory vesicles by electron microscopy. Swollen secretory vesicles finally move to the apical membrane where they fuse and release their contents into the alveolar lumen, the main milk storage area in the mammary gland.

The lipid secretory process [19] is more controversial. Earlier milk fat globule (MFG) precursors are observed on the smooth ER. Since terminal steps in triglyceride (TG) synthesis occur on the membranes of the ER, the molecules produced accumulate within the ER bilayer leaflets and would be released in the cytoplasm coated with one-half of the bilayer thus forming small intracellular lipid droplets [9, 17, 23]. During a subsequent unidirectional transport to the apical regions of the secretory cell, intracellular lipid droplets (ILD) give rise to larger droplets through a still poorly understood mechanism that would mainly consist a droplet fusion phenomena [9]. Different models of lipid droplet growth have been proposed but the main controversy lies in the mechanism by which fat globules (FG) are extruded from the cell. The most supported view considers that large ILD are progressively enveloped by the apical membrane of the cell until they are finally pinched off into the alveolar lumen [2]. MFG thus formed consist in a triglyceride core surrounded by a membrane which originates from the ER and, mainly from the apical membrane of the cell. An alternative process involving secretory vesicles has been proposed by Wooding [25] ILD would become surrounded by secretory vesicles so that cytoplasmic vacuoles containing lipid droplets (LD) partially coated by membranes are formed. Subsequent fusion with the apical membrane would release the LD in the lumen in a pseudo exocytotic phenomenon. The membrane of the so-formed FG would thus be derived from the ER, the apical membrane and the secretory vesicles. This model interestingly emphasises the close connection existing between aqueous phase secretion and lipid secretion. 


\section{GOAT MILK: APOCRINE SECRETION IS STILL CROUCHING IN THE DARKNESS}

Despite such an important and long controversy, current opinion is still that goat milk secretion is different and occurs through an apocrine process [26]. The main debate lies in the exact definition of mammary apocrine secretion and in the extent of the phenomenon [20]. The originally envisaged breakdown of the apex of the cell,

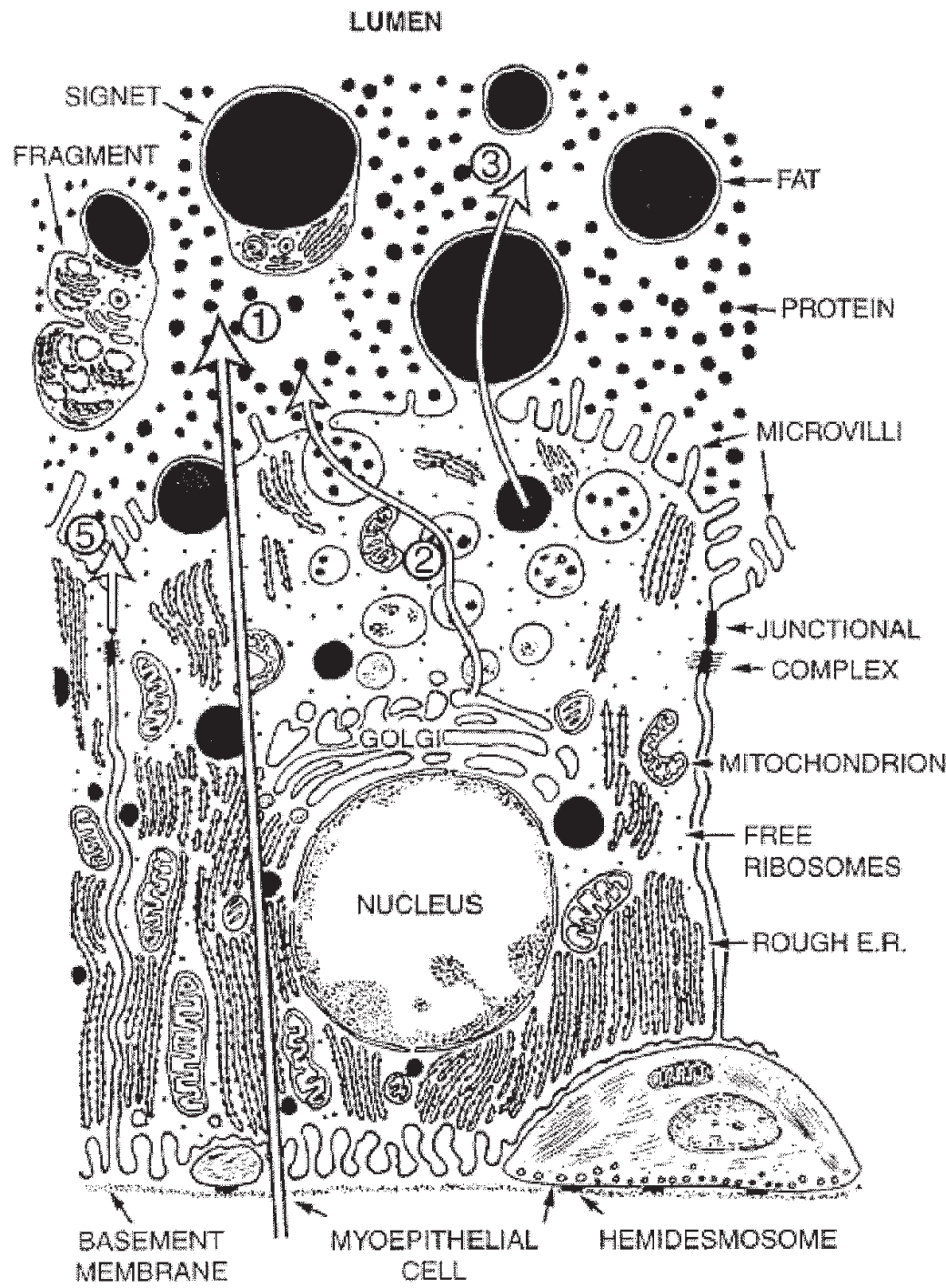

Figure 3. Diagram of the known major routes of secretion across the mammary epithelium as interpreted from electron micrographs. Pathway 1: transmembrane secretion; 2: exocytosis; 3: lipid; 5: paracellular pathway, pathway 4 (transcytosis) is not shown. (Adapted by [22] from [16].) 
exposing cytoplasm was rejected by histologists and the current vision suggests that the secretion-filled free end of the MEC is pinched off, leaving the apical membrane intact and the nucleus as well as most of the cytoplasm functional [12]. In the goat species, clues to the existence of an apocrine mechanism were found in electron microscopy studies showing numerous fat globules attached to crescents of cytoplasm (usually termed crescents or signets, Fig. 3) and various-sized fragments of secretory cells containing active organelles (except the nucleus) and several ILD (Fig. 4). The high cell contents measured in goat milk which lead to much difficulties in their current interpretation as indicators of the health of the lactating mammary gland [8] are in accordance with these observations. Interestingly, a singularity was pointed out in several published electron microscopy studies of the ultrastructure of crescents and cell fragments: both exhibit swollen ER [16]. Imagine a link between the apocrine secretion process attributed to the goat species and the observed perturbation of the secretion mechanism in association with defective $\alpha_{s 1}$-Cn $^{-}$alleles; this is thus very attractive and one must consider that most of the studies concluding to an apocrine process were carried out at times when defective alleles were still widespread in western countries.

\section{COULD THE $\alpha_{s 1}$-CASEIN POLYMORPHISM EXPLAIN THE APOCRINE MILK SECRETION PROCESS OBSERVED IN THE GOAT?}

Our objective was to find out further clues to a different way of secretion (apocrine), possibly associated with the low synthesis-rate observed with defective $\alpha_{\mathrm{s} 1}-\mathrm{Cn}$ variants in the goat species. First, on the basis of the existence of an apocrine process, traces of additional cytoplasmic contribution to the milk protein fraction had to be found in whey. Thus, the protein profiles of whey obtained by acid precipitation of high $\alpha_{\mathrm{s} 1}-\mathrm{Cn}$ level (A/A) and null type (O1/O1) pooled milks (10 homozygous animals) were compared by two-dimensional electrophoresis (2D-E). Secondly, since the ER are deeply involved in the formation of MFG via triglyceride and phospholipid biosynthesis, potential consequences of the general dysfunction observed with defective alleles occurring at the $\alpha_{s 1}$-Cn locus were investigated by comparing the structure of MFG of individual milks (10 goats/genotype) from goats of the following genotypes: $\mathrm{A} / \mathrm{A}, \mathrm{F} / \mathrm{F}$ and $\mathrm{O} 1 / \mathrm{O} 1$ corresponding to high, low and null $\alpha_{\mathrm{s} 1}$-Cn contents, respectively. Thus, MFG size, lipid and phospholipid

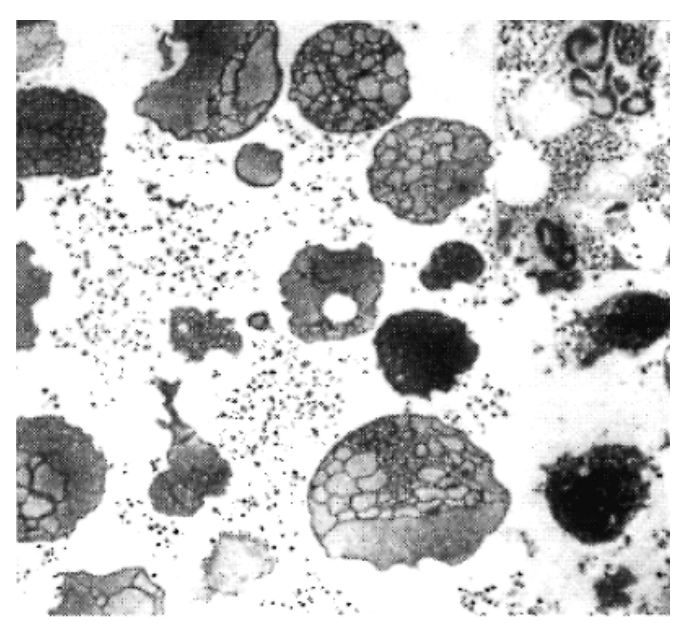

Figure 4. Cytoplasmic fragments observed by electron microscopy of the bottom layer of the pellet obtained from goat milk after fixation and soft centrifugation [26]. Note the swollen appearance of the ER in the fragments. $\times 2200$. 
composition as well as MFG membrane (MFGM) protein profiles were analysed.

2-DE maps actually revealed the presence of additional proteins in O1/O1 whey as compared with A/A whey. These proteins are currently being characterised in order to determine whether they can sign a cytoplasmic contribution consecutive to an apocrine secretion process. Milk fat fraction analysis confirmed the previously mentioned [1] effect of $\alpha_{s 1}$-Cn polymorphism on total lipid (TL) variability (AA > FF > OO) but no significant difference was recorded in phospholipid (PL) content and composition or in the protein profiles of MFGM mainly because of the great individual variability observed. Interesting data come from the proportion of PL in TL and the MFG size determination since $\alpha_{\mathrm{s} 1}$-Cn deficiency is clearly associated with a higher proportion of PL in TL and smaller MFG. Considering that PL mainly originate in membrane materials, two interpretations can be put forward. First, fat dispersion in milk is truly finer thus suggesting an internal perturbation of either lipid biosynthesis or intracellular MFG growth mechanisms. Secondly, these results translate a higher free membrane or cell fragments content in milk, possibly due to an apocrine contribution. Whatever the proposal finally retained, both are the signature of a modified secretion process associated with defective $\alpha_{\mathrm{s} 1}-\mathrm{Cn}$ variants.

The different pathways explored up to now all seem to converge towards a global effect of the $\alpha_{\mathrm{s} 1}-\mathrm{Cn}$ polymorphism and a deep involvement of this protein in the cellular mechanisms underlying the transport and secretion of milk constituents by the MEC. Additional experiments, including microscopic exploration of mammary histological slices, would provide further arguments in the favour of our hypothesis according to which the existence of an apocrine secretion process reported for the goat species is probably correlated with the perturbation of the intracellular transport of caseins induced by defective alleles at the $\alpha_{s 1^{-}} \mathrm{Cn}$ locus.

\section{REFERENCES}

[1] Barbieri M.E., Manfredi E., Elsen J.M., Ricordeau G., Bouillon J., Grosclaude F., Mahé M.F., Bibé B., Influence du locus de la caséine $\alpha_{\mathrm{s} 1}$ sur les performances laitières et les paramètres génétiques des chèvres de race Alpine, Genet. Sel. Evol. 27 (1995) 437-450.

[2] Bargmann W., Knoop A., Über die morphologie der milchsekretion Licht-und electronenmikroskopsche studien an der milch drüse der ratte, Z. Zellfirsch. 49 (1959) 344-388.

[3] Bhattacharyya J., Das K.P., Molecular chaperone-like properties of an unfolded protein $\alpha_{\mathrm{s}}$-casein, J. Biol. Chem. 274 (1999) 15505-15509.

[4] Chanat E., Martin P., Ollivier-Bousquet M., $\alpha_{s 1}$-casein is required for the efficient transport of $\beta$ and $\kappa$-casein from the endoplasmic-reticulum to the Golgi apparatus of mammary epithelial cells, J. Cell. Sci. 112 (1999) 3399-3412.

[5] Chianese L., Ferranti P., Garro G., Maurielle R., Addeo F., Occurrence of three novel $\alpha_{\text {s1 }}$-casein variants in goat milk, IDF-FIL Seminar on Milk protein polymorphism, Palmerston North, New Zealand, Proceedings, 1997, pp. 259-267.

[6] Clark S., Sherbon J.W., $\alpha_{\mathrm{s1}}$-casein, milk composition and coagulation properties of goat milk, Small. Rum. Res. 38 (2000) 123-134.

[7] Delacroix-Buchet A., Degas C., Lamberet G., Vassal L., Influence des variants AA et FF de la caséine $\alpha_{\mathrm{s} 1}$-caprine sur le rendement fromager et les caractéristiques sensorielles des fromages, Lait 76 (1996) 217-241.

[8] Dulin A.M., Paape M.J., Wergin W.P., Differentiation and enumeration of somatic cells in goat milk, J. Food Prot. 45 (1982) 435-439.

[9] Dylewski P., Dapper C.H., Valivullah H.M., Deeney J.T., Keenan T.W., Morphological and biochemical characterization of possible intracellular precursors of milk lipid globules, Eur. J. Cell. Biol. 35 (1984) 99-111.

[10] Grosclaude F., Martin P., Casein polymorphism in the goat, IDF-FIL Seminar on Milk protein polymorphism, Palmerston North, New Zealand, Proceedings, 1997, pp. 241-253.

[11] Grosclaude F., Mahé M.F., Brignon G., Di Stasio L., Jeunet R., A mendelian polymorphism underlying quantitative variations of goat $\alpha_{\mathrm{s} 1}$-casein, Genet. Sel. Evol. 19 (1987) 399-412.

[12] Kurosumi K., Electronmicroscopic analysis of secretion mechanism, Intern. Rev. Cytol. 11 (1961) 1-124. 
[13] Jansa Pérez M.J., Leroux C., Sanchez Bonastre A., Martin P., Occurrence of a LINE sequence in the 3'UTR of the goat $\alpha_{\mathrm{s} 1}$-casein E encoding allele associated with a reduced protein synthesis level, Gene 147 (1994) 177-179.

[14] Lamberet G., Degas C., Delacroix-Buchet A., Vassal L., Influence de caractères liés aux allèles $\mathrm{A}$ et $\mathrm{F}$ de la caséine $\alpha_{\mathrm{s} 1}$ caprine sur la flaveur de chèvre : fabrications fromagères avec échanges de protéines et de matières grasses, Lait 76 (1996) 349-361.

[15] Leroux C., Mazure N., Martin P., Mutations away from splice site recognition sequences might cis-modulate alternative splicing of goat $\alpha_{\mathrm{s} 1}$-casein transcripts. Structural organization of the revelant gene, J. Biol. Chem. 267 (1992) 6147-6157.

[16] Linzell J.L., Peaker M., Mechanism of milk secretion, Physiol. Rev. 51 (1971) 564-597.

[17] Long C.A., Patton S., Formation of intracellular fat droplets: interrelation of newly synthesized phosphatidyl-choline and triglycerides in milk, J. Dairy Sci. 61 (1978) 1392-1399.

[18] Martin P., Leroux C., Characterisation of a further $\alpha_{\mathrm{s} 1}$-casein variant generated by exon-skipping, 24th ISAG Conference, Prague, Abstract E. 43 , p. 88 .
[19] Mather I.H., Keenan T.W., Origin and secretion of milk lipids, J. Mammary Gland Biol. Neoplasia 3 (1998) 259-273.

[20] Patton S., Nature 228 (1970) 97.

[21] Remeuf F., Influence du polymorphisme de la caséine $\alpha_{\mathrm{s} 1}$ caprine sur les caractéristiques physico-chimiques et technologiques du lait, Lait 73 (1993) 549-557.

[22] Shennan D.B., Peaker M., Transport of milk constituents by the mammary gland, Physiol. Rev. 80 (2000) 925-951.

[23] Scow R.O., Blanchette-Mackie E.J., Smith L.C., Transport of lipids across capillary endothelium, Fed. Proc. 39 (1980) 2610-2617.

[24] Vassal L., Delacroix-Buchet A., Bouillon J., Influence des variants AA, EE et FF de la caséine $\alpha_{\mathrm{s} 1}$ caprine sur le rendement fromager et les caractéristiques sensorielles de fromages traditionnels : premières observations, Lait 74 (1994) 89-103.

[25] Wooding F.B.P., The mechanism of secretion of the milk fat globule, J. Cell Sci. 9 (1971) 805-821.

[26] Wooding F.B.P., Peaker M., Linzell J.L., Theories of milk secretion: evidence from electron microscopic examination of milk, Nature 226 (1970) 762-764.

To access this journal online: www.edpsciences.org 